\title{
Feed intake, molt frequency, tissue growth, feed efficiency and energy budget during a molt cycle of mud crab juveniles, Scylla serrata (Forskål, 1775), fed on different practical diets with graded levels of soy protein concentrate as main source of protein
}

\author{
Ngoc Thi Bich Nguyen ${ }^{\mathrm{a}, \mathrm{b}, \mathrm{c},{ }^{*}, \text { Liet Chim }}{ }^{\mathrm{b}}$, Pierrette Lemaire ${ }^{\mathrm{b}}$, Laurent Wantiez ${ }^{\mathrm{a}}$
}

\author{
${ }^{a}$ LIVE EA4243, University of New Caledonia, 98851 Noumea Cedex, New Caledonia \\ b IFREMER, Délégation de Nouvelle-Calédonie, BP 2059, 98846 Noumea Cedex, New Caledonia \\ ${ }^{c}$ RIA3, Research Institute for Aquaculture No. 3, 33 Dang Tat, Nha Trang, Viet Nam
}

*: Corresponding author : Ngoc Thi Bich Nguyen, email address : ntbngoc33@gmail.com

\begin{abstract}
:
There has been growing interest in the development of mud crab aquaculture in New Caledonia. However, for this to become established at a commercial level, a cost-effective formulated feed based on internationally-available ingredients needs to be developed. We have evaluated the optimal dietary protein content for juvenile crabs, Scylla serrata (Forskål, 1775), using a series of diets with a protein content ranging from 27 to $49 \%$ and soy protein concentrate (SPC) as the main protein source. For this purpose, 54 individually housed crabs were allocated to five dietary treatments $(n=10$ or 11). The crabs were fed ad libitum, for 81 days with the allocated diets. The apparent digestibilities of dry mater, crude protein and energy were high (96.2-97.3\%), irrespective of the diet. The voluntary feed intake (VFI) of crabs widely varied from 46 to $220 \mathrm{~g} \mathrm{~kg}^{-1}$ of fresh initial body weight per week (iBW week ${ }^{-1}$ ) whatever the diet. However, SPC intake and protein intake increased significantly with dietary protein content up to the diet with $40 \%$ crude protein, but did not increase further with diets containing $44 \%$ and $49 \%$ crude protein. The cumulative molts were strongly affected by the VFI levels or energy intake and also, to a lesser extent, by the levels of SPC or protein in diets. Two phases in tissue gain were observed after ecdysis: an initial deposition phase lasting around 30 days followed by a plateau which lasted until the next molt. The daily tissue growth was $16.5 \%$ of dry body weight (dry BW) one day after ecdysis and dramatically decreased to $3.6 \%$ of dry BW over the first 10 days, then decreased more slowly to the minimum value of $1.3 \%$ of dry BW over the next 70 days. During the course of experiment, the best growth (tissue growth and molt frequency) and the best feed efficiency (FCR, PER, retention of proteins and lipids) were obtained with crabs fed on the diet with $40 \%$ crude protein. This result was confirmed by a bioenergetic study which showed significantly higher allocation of the energy intake for growth (RE) of crabs fed on diet $40 \%$ crude protein. Finally, under our experimental conditions, $1 \mathrm{~kg}$ of juvenile crabs required $6.5 \pm 1.1 \mathrm{~g}$ of protein per day. This level was obtained with the diet SPC-42 that contained $40 \%$ of protein of which almost three quarters were derived from SPC. Two hypotheses are proposed to explain the negative effect of high level of SPC or protein on growth and feed efficiency for crabs fed on in diets containing $52 \%$ and $60 \%$ SPC.
\end{abstract}




\section{Highlights}

There were two tissue growth periods of crabs during a molt cycle: FTG (Fast tissue growth) corresponding to postmolt period and STG (Slow tissue growth) corresponding to intermolt \& premolt periods. Protein, lipid and ash gain during one molt cycle correlated to tissue growth model.

Voluntary feed intake (VFI) followed the same trend with tissue growth. VFI or energy intake had a strong effect on molt frequency or intermolt cycle. Higher VFI level resulted in higher cumulative molts. - Crabs fed on diet SPC-42 (40\% crude protein content in which $3 / 4$ from soy protein concentrateSPC) exhibited the best growth (tissue growth and molt frequency) then leading the highest feed efficiency (FCR, PRE, retention of protein and lipid). N No effect of different SPC levels in the dietary diets on size increment after molt. - Highest and lowest energy intake respectively allocated in RE (growth energy), HEm (maintenance energy) were observed for crabs fed on SPC-42.

Keywords : Scylla serrata ; Tissue growth ; Feed efficiency ; Protein requirement ; Soy protein concentrate ; Energy budget 


\section{Introduction}

Mud crab aquaculture has been cultured for many years in Southeast Asia, based primarily on the capture and fattening of juvenile crabs from the wild, particularly in Vietnam where production is increasing quickly (Petersen et al., 2013). There is an unmet demand for mud crabs and this has led to over-exploitation of wild populations in many areas (Vega-Villasante et al., 2007). Difficulties in obtaining wild caught juveniles for farming operations, and concerns about further over-exploitation have led to major investments in the development of new hatchery techniques (Allan and Fielder, 2003). For the past few years, techniques for breeding in captivity and larval rearing have been developed allowing production to triple in 5 years (from 10,000 tons in 2004 to 30,000 in 2009) (John and Paul, 2012). However, the substantial crab farming operations which now exist throughout Southeast Asia are still mainly based on wild caught crablets (Allan and Fielder, 2003) and animals in captivity are fed with excessive amounts of trash fish which contaminate the rearing water and lead to high mortality rates (Linder, 2005).

In New Caledonia, there is a strong political wish to diversify aquaculture, which until recently, has been based on blue shrimp (Litopenaeus stylirostris) farming. Among the different options available, the mud crab, Scylla serrata, is regarded as having great potential for aquaculture through its farming characteristics and its high economic value (Shelley and Lovatelli, 2011). However, the possible development of crab farming in New Caledonia will require the development of an artificial feed that can be produced from selected and controlled raw materials that are available on the international market.

Therefore, it is essential to assess the nutritional requirements of $S$. serrata. A few studies have been carried out on this subject. Sheen and Wu (1999) showed better utilization of lipids by the crab than by shrimp through a study in which they measured the growth response of juvenile crabs that has been fed diets with a range of inclusion levels of a mixture of cod liver oil and corn oil. Later, Sheen (2000) indicated the importance of a dietary source of cholesterol and polyunsaturated fatty acids (22:6n-3, 20:4n-6, 18:3n-3) for the healthy growth of juvenile crabs. Furthermore, a series of studies have been carried out to measure the digestibility of several potential ingredients for formulated feed for crabs (Catacutan et al., 2003; Truong et al., 2009). These results showed that crabs were able to digest many different ingredients, in particular fibre and protein from plants. Finally, the optimal protein inclusion level in the diet has been the subject of two studies (Catacutan, 2002; Unnikrishnan and 
Paulraj, 2010). Both studies concluded that the optimal protein concentration (a mixture of fish meal and soybean meal) in the feed for the best growth rate is between $30 \%$ and $47 \%$.

Feed for aquaculture generally requires large quantities of ingredients from the sea and this sector is the largest consumer of fish meal among the animal husbandry subsectors (Shepherd and Jackson, 2013). Indeed, fish meal is the primary source of protein and energy in most aquafeeds and accounts for up to $75 \%$ of the mass of total aquaculture feed (Tacon and Dominy, 1999). In 1989, fish meal used in aquaculture accounted for only $10 \%$ of global production (FAO, 2000), this had dramatically increased to 73\% by 2010 (Shepherd and Jackson, 2013). Production of carnivorous species, promoted in aquaculture, particularly marine crustaceans, marine finfish and salmonids, requires a lot of fish meal (Rana et al., 2009). The cost of fish meal is increasing over time as a result of the increased competition for available supplies (Sookying et al., 2013). Hammersmith Marketing Ltd (2008) indicated that the price of fish meal increased by about 62.9\% from August 2005 to June 2008. In these conditions, feed can account for as much as $40-60 \%$ of the cost in aquaculture production (Hertrampf and Piedad-Pascual, 2000). In this framework, partially or completely shifting from a fish meal protein source to more sustainable protein sources in formulated feeds is a priority for sustainable mud crab aquaculture development (Christense et al., 2004; Tuan et al., 2006).

Many plant-based ingredients are used as a source of proteins in aquafeeds. Among them, soybean meal (SBM) is well known for its relatively high protein content, well balanced amino acid profile, and stable market supply, as well as its reasonable cost (Davis and Arnold, 2000; Amaya et al., 2007a,b). Chen et al. (1994) reported that up to $33 \%$ fish meal protein could be replaced by soybean cake for juvenile mitten crab without reducing growth. Recently, Luo et al. (2011) found that 30\% inclusion of soybean meal and rapeseed meal mixture (1:1 ratio) could replace $40 \%$ fish meal in diets for Chinese mitten crab without impairing growth performance and feed utilization. However, the inclusion of SBM in fish diets has been limited by relatively high levels of heat stable antinutritional and antigenic factors including protease inhibitors, oligosaccharides (e.g., stachyose, raffinose), saponins, isoflavones, phytate, and tannins (Francis et al., 2001). Although heat and enzyme treatments can neutralize some of these compounds, they are still a significant problem when including SBM in aquaculture feeds (Gatlin et al., 2007). Soy protein concentrate (SPC), although more expensive than SBM, does not contain the alcohol-soluble fraction present in SBM and has a higher essential amino acid concentration. It also has greater nutrient digestibility compared 
with SBM and can be included at much higher concentrations in diets of piscivorous marine species (Bureau et al., 1998; USSEC, 2008). Recently we showed that SPC is well digested and able to replace the fishmeal as the main source protein for crab juveniles S. serrata (unpublished).

Most of the previous studies have considered growth rate as gains in fresh weight. Fresh weight changes follow a basic pattern through the molt cycle, i.e. large and abrupt increases associated with rapid water uptake at ecdysis; further moderate gains associated with carapace mineralization and tissue growth during postmolt and relative stabilization of fresh weight during intermolt until the onset of the successive ecdysis (Heasmen, 1980). Increase in tissue mass, on the other hand, is a continuous process occurring through the molt cycle (Freeman, 1990). The tissue growth can be measured as the increase in dry weight as tissues lose water in direct proportion to their gain in dry mass (Passano, 1960). In this paper we report on the response of juvenile crabs $S$. serrata to graded levels of soy protein concentrate and respective dietary proteins on growth (somatic growth and molt frequency), feed efficiency (feed conversion efficiency-FCR; protein efficiency ratio-PER; retentions of protein, lipid and energy) and energy budget.

\section{Materials and methods}

\subsection{Crabs and holding facilities}

A total of juvenile crabs, S. serrata, were collected from the mangrove habitat surrounding the experimental station $\left(21^{\circ} 51^{\prime} 50^{\prime \prime} \mathrm{S}, 166^{\circ} 3^{\prime} 0^{\prime \prime} \mathrm{E}\right)$ in the Boulouparis district, New Caledonia. Seventy juvenile crabs were caught using a hand net racket and transferred to the laboratory and acclimated into 8 circular composite tanks (capacity $500 \mathrm{~L}$ ) for one week prior to the beginning of the experiment. The crabs were examined to identify their molt stage using the criteria and methodology described by Drach and Tchernigovtzeff (1967), Freman et al. (1987) and Heasman (1980). Fifty four of the crabs were identified as being in intermolt stage and were selected for the experiment. These crabs were randomly and individually assigned to fifty four experimental rectangular polyethylene tanks $(30 \times 20 \times 30 \mathrm{~cm})$ covered with black lids. After being dried in soft paper and cotton cloth, each crab was weighed to the nearest $0.01 \mathrm{~g}$ by the Scientech $^{\circledR}$, SL 3000 balance and its carapace width was measured to the nearest $0.01 \mathrm{~mm}$.

Each experimental tank was continuously supplied with seawater running from a polyethylene reservoir (2000 L capacity) at the rate of $0.19 \mathrm{~L} \mathrm{~min}^{-1}$. The water pumped from the lagoon was 
filtered through a $25 \mu \mathrm{m}$ net bag into the reservoir. The temperature was automatically controlled using a $300 \mathrm{w}$, French heater. The temperature in the experimental tanks was measured every 3 hours using an automatic recording probe. During the experimental period, water environmental parameters were maintained with: $\mathrm{T}^{\circ} \mathrm{C}=21.5 \pm 2.5, \mathrm{~S} \%{ }_{0}=34.0 \pm 1.5$, $\mathrm{pH}=7.97 \pm 0.09$ and $\mathrm{O}_{2}=4.48 \pm 0.16 \mathrm{mg} \mathrm{L}^{-1}$.

\subsection{Diet preparation and composition}

The crabs were fed on five different experimental diets (SPC-12; SPC-32; SPC-42; SPC-52; and SPC-60) formulated with graded levels of SPC as a main source of protein (Table 1). The diets were produced in the laboratory using the following procedure: the dry ingredients were ground up in a grinder (Retsch® SR200, Gemany) with a $1 \mathrm{~mm}$ screen. The meal obtained was mixed with oil and water (30\%) in a horizontal mixer (Mainca ${ }^{\circledR}$ RM-90-135, USA) until the consistency was suitable for pelleting. The mixture was then extruded through a $3 \mathrm{~mm}$ die in a meat grinder. Pellets were steamed for $15 \mathrm{~min}$ and stored at $-20^{\circ} \mathrm{C}$ before use (Truong et al., 2008; Unnikrishnan and Paulraj, 2010). The ingredient compositions and proximate nutrient contents of experimental diets are shown in Table 1.

\subsection{Experimental design}

\subsubsection{Growth trial}

At the beginning of the experiment, the crabs were starved for 48 hours for weaning to the dietary diets and then weighed and measured. The initial average body weight and carapace size of the crabs was $20.43 \pm 9.81 \mathrm{~g}$ and $4.92 \pm 0.81 \mathrm{~cm}$, respectively. As each crab was held separately, the experimental unit in this study was the individual. Fifty four tanks with individual crabs were assigned to the five different dietary treatments. Thus, 11 tanks were randomly assigned to each treatment $(n=11)$, except for the treatment with diet SPC-12 $(n=$ 10). The crabs were fed once each day ad libitum. The daily pre-weighed feed allocation for each tank was delivered at 6:00-7:00 am. Three hours after each meal, the uneaten feed was siphoned off, dried 24 hours at $60{ }^{\circ} \mathrm{C}$ and weighed (Unnikrishnan and Paulraj, 2010).

The leaching rate (dry matter loss of the pellet in the water) was determined by using the method described in Johnston and Johnston (2007). A weighted quantity of each diet was placed in a 1-L glass beaker filled with $800 \mathrm{~mL}$ of seawater, gently aerated and then incubated in a water bath at $22{ }^{\circ} \mathrm{C}$ for $3 \mathrm{~h}$. The amount of voluntary feed intake (VFI) for each crab was obtained following this equation:

$\mathrm{VFI}=\mathrm{dF}-\mathrm{L}-\mathrm{uF}$ 
Where: $\mathrm{VFI}=$ voluntary feed intake; $\mathrm{dF}=$ distributed feed; $\mathrm{L}=$ leaching after 3 hours and $\mathrm{uF}$ $=$ unconsumed feed.

During the experimental period, the date of ecdysis, carapace width and live body weight were recorded for each crab after molting, and then they were transferred back to the tanks. The exuviae were collected and weighed before and after drying at $80{ }^{\circ} \mathrm{C}$ for $24 \mathrm{~h}$, then kept at $-20{ }^{\circ} \mathrm{C}$ for energy analysis. The trial was maintained for 81 days. At the end of the experiment, all of the crabs were left unfed for $48 \mathrm{~h}$ and then weighed, measured, dried at 80 ${ }^{\circ} \mathrm{C}$ for $48 \mathrm{~h}$ and kept at $-20^{\circ} \mathrm{C}$ before biochemical and energy analysis.

\subsubsection{Digestibility trial}

All diets contained $1 \%$ chromic oxide $\left(\mathrm{Cr}_{2} \mathrm{O}_{3}\right)$ as an inert maker to allow the calculation of digestibility coefficients (ADC) for dry matter (ADMD), crude protein (ACPD) and gross energy (AGED). The chromium content of diets and fecal material used to calculate apparent digestibility values were determined using the method described by Furukawa and Tsukahara (1966). Apparent digestibilities of dry matter (ADMD), crude protein (ACPD) and gross energy (AGED) were calculated following the equations:

$\mathrm{ADMD}=100-100\left(\% \mathrm{Cr}_{2} \mathrm{O}_{3}\right.$ in feed $/ \% \mathrm{Cr}_{2} \mathrm{O}_{3}$ in feces $)$

ACPD or AGED = $100-100\left[\left(\% \mathrm{Cr}_{2} \mathrm{O}_{3}\right.\right.$ in feed $/ \% \mathrm{Cr}_{2} \mathrm{O}_{3}$ in feces $) \mathrm{x}\left(\%\right.$ protein or $\mathrm{MJ} \mathrm{kg}^{-1}$ energy in feces/ \% protein or $\mathrm{MJ} \mathrm{kg}^{-1}$ energy in feed)].

\subsubsection{Nitrogenous excretion trial}

Three crabs from each treatment were individually fed ad libitum with their assigned experimental diet. Immediately after the meal, each crab was transferred into another individual aquarium containing a fixed volume of water $(10 \mathrm{~L})$. Ammonia-N excretion in each aquarium was measured twice: before and $24 \mathrm{~h}$ after transferring the crab, using the method described in Grasshoff (1983). The ammonia-N value was converted into energy by multiplying by $24.83 \mathrm{~kJ} \mathrm{~g}^{-1}$ (Elliot, 1976). The potential loss of nitrogenous compounds through bacterial action or diffusion was quantified by setting controls without crabs. The values of ammonia-N concentration of this control treament were used to adjust determined nitrogenous excretion. During the experimental period, this excretion trial was repeated every 25 days to get the average value for ammonia-N excretion.

\subsection{Biochemical analysis}


The proximate compositions of diets, feces, initial and final crabs were determined at the Invivo laboratory, Vietnam according to the methods of AOAC (1995). Moisture contents of crabs and feed were determined after oven-drying to a constant weight at $105{ }^{\circ} \mathrm{C}$. Each sample was combusted at high temperature in pure oxygen then the nitrogen content was measured by thermal conductivity detection and converted to equivalent protein content by an appropriate numerical factor, crude protein $\%=\% \mathrm{~N} * 6.25$. Crude lipid content was measured by solvent extraction with petroleum ether. Ash content was determined following combustion in a muffle furnace at $550{ }^{\circ} \mathrm{C}$ for 8-10 h. Energy contents of diets, fecal material, exuviae and crabs were determined by calorimetric bomb (Parr® 6200, USA, calibrated by benzoic acid) at Ifremer laboratory, New Caledonia.

\subsection{Definitions, calculations and statistics}

\subsubsection{Monitoring the molting}

Cumulative molting $(\mathrm{CM}, \%)$ can be calculated using the following formula:

$\mathrm{CM}=\left(\sum_{i-0}^{n} \mathrm{Mi} / \mathrm{Cr}\right) \times 100$

Where $\mathrm{i}=$ the day $\mathrm{i} ; \mathrm{Mi}=$ number of molts on the day $\mathrm{i} ; \mathrm{Cr}=$ number of crabs in each treatment.

\subsubsection{Growth measurements}

Growth parameters of crabs in this study were determined as: tissue growth rate, tissue gain and nutrient gains (protein, lipid and ash). iBW and BWa.e. are initial body weight and body weight after ecdysis, respectively; fBW is final dry body weight. Dry BWa.e. was $15 \%$ of total body weight of 1 day-molted crab estimating from our extra sample assessment for 12 crabs molted after 1 day.

Tissue growth rate after ecdysis (\% of dry BWa.e. $\left.\mathrm{d}^{-1}\right)$ or during the course of experiment (\% of dry $\mathrm{iBW} \mathrm{d} \mathrm{d}^{-1}$ ) and tissue gain (\% of dry BWa.e.) were measured on the basis of the increase in dry weight (Passano, 1960):

Tissue growth rate after ecdysis $=100$ [(fBW - dry BWa.e.) - ash gained] / (dry BWa.e. $x$ days after ecdysis)

Tissue growth rate during the course of experiment $=100[(\mathrm{fBW}-$ dry $\mathrm{iBW})-$ ash gained $] /$ (dry iBW x days of experiment)

Tissue gain $=100[(\mathrm{fBW}-$ BWa.e. $)$ - ash gained $] /$ BWa.e. 
Protein, lipid or ash gain $=100$ (protein, lipid or ash retained) $/$ BWa.e.,

\subsubsection{Feed efficiency}

Feed conversion ratio (FCR) was calculated as:

$\mathrm{FCR}=$ dry voluntary feed intake/dry weight gain

Protein efficiency ratio (PER) was calculated as:

PER = dry weight gain/total protein ingested

Protein, lipid or energy retention was calculated as:

Protein, lipid or energy retention $(\%)=100 \mathrm{x}$ (protein, lipid or energy retained/total protein, lipid or energy intake).

\subsubsection{Energy budget assessment}

The partitions of the energy budget suggested by the National Research Council (NRC, 2011) were adopted in this study with minor modification in order to comply with mud crab growth through ecdysis. The energy budget of growing crabs is expressed in our study as:

$\mathrm{IE}=\mathrm{FE}+\mathrm{UE}+\mathrm{SE}+\mathrm{RE}+\mathrm{HE}_{\mathrm{m}}(1)$

Where IE = the energy intake which was obtained for each crab by calculating the difference between the feed distributed and the feed leached and uneaten;

$\mathrm{FE}=$ energy lost from the animal through the feces for each crab, FE was calculated by the difference betwwen the voluntary feed intake and the digested feed estimated from its apparent digestibility;

$\mathrm{UE}=$ energy lost from the animal through the total ammonia excretion which was asseesed for each crab from the trial of nitrogenous excetion previously indicated;

$\mathrm{SE}=$ surface energy losses which is exuvia lost at ecdysis;

$\mathrm{RE}=$ recovered energy which is channeled into growth. It was calculated for each crab through the dry weight gain converted into energy;

$\mathrm{HE}_{\mathrm{m}}=$ maintenance energy calculated for each crab from the equation (1):

$\mathrm{HE}_{\mathrm{m}}=\mathrm{IE}-(\mathrm{FE}+\mathrm{UE}+\mathrm{SE}+\mathrm{RE})$

\subsubsection{Statistical analysis}


Differences among the various treatments were considered significant when $P<0.05$. Shapiro-Wilk and Levene's test were used for checking normality and homogeneity of variances, respectively. Percentage data were transformed to their arcsine values to get a normal distribution of the data. One-way ANOVA was applied to i) test the effect of dietary treatments on VFI, and ii) compare the digestibility coefficient of each diet. ANCOVA was used with energy intake as a covariate to assess the effect of the different diets on the tissue growth, feed efficiency parameters (FCR, PER, retention of protein, lipid, and energy), and the partitioning of the energy budget.

\section{Results}

\subsection{Feed digestibility and voluntary intake}

Apparent digestibility for dry matter (ADMD), crude protein (ACPD) and gross energy (AGED) of the five experimental diets are given in Table 2. No significant differences between diets (ANOVA, $P>0.05$ ) in ADMD, ACPD and AGED were found; apparent digestibilities were high with average values of $96.02 \pm 1.59 \%$ for ADMD; $97.26 \pm 0.66 \%$ for ACPD and $97.02 \pm 0.54 \%$ for AGED

The averages of voluntary feed intake (VFI), soy protein concentrate (SPC) and protein intakes for each diet are presented in Table 3. There were no significant differences in VFI (ANOVA, $P=0.78$ ) among the treatments. However, the variability of the data was high whatever the diet $(\mathrm{CV}=36.7 \%, \mathrm{n}=50)$ with a minimum VFI of 45.7 and maximum of 220.2 $\mathrm{g} \mathrm{kg}^{-1}$ of fresh iBW week ${ }^{-1}$. Soy and protein intakes significantly increased from the diet SPC12 to the diet SPC-42 and then reached a plateau for the two following diets with higher inclusion levels of SPC.

As VFI was not affected by the diet composition, we pooled all the data to study the feed consumption during the course of the experiment (Fig. 1). During the first 14 days after ecdysis, crabs consumed about $200 \mathrm{~g} \mathrm{~kg}^{-1}$ of fresh iBW week ${ }^{-1}$ and then the VFI decreased until Day 35. From Day 49 until the Day 77, VFI remained at a baseline value of around 100 $\mathrm{g} \mathrm{kg}^{-1}$ fresh iBW week ${ }^{-1}$. Over the last 5 days before ecdysis, the VFI dropped dramatically to the value of $50 \mathrm{~g} \mathrm{~kg}^{-1}$ of fresh $\mathrm{iBW}$ week ${ }^{-1}$.

\subsection{Molt cycle}

The cumulative molts were clearly affected by the voluntary feed or energy intake levels, all diets combined (Fig. 2A). Two crab groups were identified; a low VFI group $(1.05 \pm 0.12 \%$ of 
iBW d $\left.\mathrm{d}^{-1}\right)$ and a high VFI group $\left(1.97 \pm 0.12 \% \mathrm{iBW} \mathrm{d}^{-1}\right)$. Cumulative molts, during the course of experiment were $50 \%$ and $100 \%$, respectively in the low and high VFI groups.

The cumulated molts were also affected by the SPC or protein contents in the diets (Fig. 2B). After 80 days, the molting rates was $60 \%$ for crabs fed on the diets SPC-12, and $90 \%$ for crabs fed on the diets SPC-32, SPC-52 and SPC-60. Whereas, only 50 days after starting the experiment, $90 \%$ of the crabs fed on diet SPC-42 had molted.

\subsection{Growth}

\subsubsection{Body weight gain and carapace increment at molt}

The fresh weight gain after ecdysis (molt stage B) averaged $89.5 \pm 4.1 \%$. It was not affected by the diet, except significantly higher (ANOVA, $P<0.05$ ) for crabs fed on diet SPC-42 compared with SPC-52 (Fig. 3A). The average carapace increment was $23 \pm 2.7 \%$ and was not affected by the diet consumed (Fig. 3B).

\subsubsection{Tissue growth during molt cycle}

The water content of postmolt crabs was $85 \%$ one day after ecdysis (Fig. 4) and then decreased over the next 23 days to reach a baseline of $62.4 \pm 0.6 \%$ of water which then remained relatively constant until the next molt.

The tissue gain, measured as the increase in dry organic matter as proportion of dry body weight after ecdysis (BWa.e.), increased for about 30 days after ecdysis and then it remained relatively constant until the next molt (Fig. 5A).

The tissue growth rate was highest two days after ecdysis (16.5\%) and dropped dramatically during the first 10 days to $3.6 \%$. Then the decrease was slower to the minimum value of $1.3 \%$ just before the next ecdysis (Fig. 5B).

Crab body protein and lipid change during the intermolt cycle and showed the same trend as the tissue growth (Fig. 6A, 6B, respectively) with two distinct phases: an initial increase followed by a plateau. The initial increase of body protein content started about one week earlier than the increase of the lipids. Ash gain did not follow the trends of protein and lipid. It increased rapidly during the first five days after ecdysis and then remained stable during most of the intermolt period (Fig. 6C).

\subsubsection{Tissue growth and feed efficiency according to the dietary treatments}

To compare the effect of the different diets on growth, feed efficiency and energy budget, only the crabs which had molted a minimum of 30 days before and had reached the plateau of 
their tissue growth were retained for the experiment. In the treatment SPC-12, only 2 crabs satisfied this condition, thus we have not considered this treatment any further.

As voluntary feed intake (VFI) was highly variable, regardless of dietary treatment, we have to consider the effect of its level on crab tissue growth. Indeed, there is a significant linear relation between energy intake and growth rate for each dietary treatment, with the exception of diet SPC-32 which however has linear relationship (Fig. 7). Thus, ANCOVA was applied for all the diet treatments with energy intake as a covariate in order to reduce error variance within each treatment allowing us to more accurately assess the effect of dietary treatment on dependent parameters (tissue growth, feed efficiency).

Based on analysis of covariance (ANCOVA), dietary treatments did not significantly affect tissue growth rate $(P=0.054)$, nor the FCR $(P=0.135)$, PER $(P=0.127)$ and protein retention $(P=0.112)$, but they did affect lipid retention $(P<0.001)$, and energy retention $(P=$ 0.013) (Table 4). For lipid retention, the highest values were found for the diet SPC-32 and SPC-42 and then it decreased with the diet SPC-52 and SPC-60. For energy retention there was no clear trend, with lowest value for diet SPC-32 and SPC-52 and highest values for diets SPC-42 and SPC-60.

\subsubsection{Energy budget according the dietary treatments}

To analyze the energy budgets for the different diets only crab juveniles which had molted a minimum of 30 days before were retained for the experiment.

ANCOVA analysis showed that the dietary treatments did not significantly affect the energy budget allocated in FE $(P=0.15)$ and SE $(P=0.26)$. Conversely, diet affected UE $(P<$ $0.001)$, RE $(P=0.005)$, and $\mathrm{HE}_{\mathrm{m}}(P=0.01)$. UE increased in the similar way to SPC or protein content in the diets with significant rise for SPC-52 and SPC-60 (Table 5).

For $\mathrm{RE}$ and $\mathrm{HE}_{\mathrm{m}}$, there were no clear pattern but we noted significantly higher value for $\mathrm{RE}$ and lower for HEm with crabs fed on diet SPC-42. The average energy budget accounted for RE was higher for crabs fed on diets SPC-32 and SPC-42 compared to other diets; however, this difference was not significant.

Under our experimental conditions, the main proportion of energy intake was allocated for maintenance $(75 \%)$ and growth $(21 \%)$. The remaining proportion of energy intake (4\%) was shared among FE (2.5\%), UE (0.6\%) and SE (0.9\%).

\section{Discussions and conclusions}




\subsection{Feeds digestibility}

In our study, digestibility of the experimental diets was not affected by the level of dietary soy protein concentrate (SPC). This result confirms the results of our previous study on crab $S$. serrata that showed high digestibility coefficients for dry matter, protein and energy of SPC, which were also similar to those of fish meal (unpublished). These results are also consistent with previous studies on mud crabs reporting high soybean meal digestibility at an inclusion level of up to $45 \%$, with ADC values for ADMD, ACPD and AGED ranging from 80.4 to $95.7 \%$; 91.7 to $97.1 \%$ and 88.6 to 97.9 , respectively (Catacutan et al., 2003; Tuan et al., 2006; Truong et al., 2008, 2009). Furthermore, Truong et al. (2008) showed that crude protein from soy bean meal was more completely digested by mud crabs than the other plant ingredients tested (canola, lupin and cotton seed meal). Although SPC is more expensive than $\mathrm{SBM}$, it does not contain the alcohol-soluble fraction present in SBM and has a higher essential amino acid concentration. It also has greater nutrient digestibility compared with $\mathrm{SBM}$ and can be included at much higher concentrations in diets of piscivorous marine species (Bureau et al., 1998; USSEC, 2008).

\subsection{Voluntary feed intake (VFI)}

In the present study, VFI varies greatly between individuals (global CV $=36.7 \%$ ) with a general average of $105.5 \mathrm{~g} \mathrm{~kg}^{-1}$ of iBW week ${ }^{-1}$. As the experimental diets were formulated to be isoenergetic, the variability of energy intake was similar to the VFI variability. Interestingly, the average VFI did not differ among diets tested, even the corresponding SPC intake increased significantly as its concentration in the diet increased. Jiang et al. (2013) obtained a similar result with the crab Eriocheir sinensis and Suárez et al. (2009) showed no difference in feed intake for the shrimp Litopenaeus vannamei when the replacement of fish meal by soybean-canola meal reached $100 \%$. Nevertheless, Luo et al. (2011) reported that feed intake of Chinese mitten crab (Eriocheir sinensis) was significantly reduced when a mixed source of dietary soybean meal and rapeseed meal exceeded $30 \%$. As the VFI were very variable in our study, whatever the diet tested, the amount of protein or SPC ingested relied not only on the diet composition (dietary level of SPC) but also on the VFI. Thus, several crabs fed on the diets with higher protein contents, did in fact ingest less protein than some animals fed on diets with lower protein contents. However, the general trend showed that the protein intake increased significantly from the diet SPC-12 to the diet SPC-42 and then remained stable. Consequently, the surplus of SPC in the diets SPC-52 and SPC-60 did 
not result in higher protein consumption. We can then assume that the diet SPC-42 is the best compromise between dietary levels of SPC and availability of proteins for crabs.

\subsection{Molt frequency}

The duration of molt cycle stages in S. serrata (and all decapod crustaceans) are the net result of complex interactions between many endogenous (genetic) and exogenous factors (Heasman, 1980). Amongst these factors, temperature, nutrition, autotomy and regeneration, size and sex and sexual maturity are important (Heasman, 1980). Few studies have been devoted to the quantitative and still less to the qualitative influence of nutrition on the molting frequency of crustaceans. However, the general trend is that if food supply is reduced below the optimum level, there is invariably a reduction in growth rate (Hartnoll, 1982). This reduction is due to the combination of an extended intermolt period (lower molt frequency) and a reduced molt increment (carapace and body weight growth at molt). Our study confirmed this trend as the level of voluntary food intake (VFI) greatly influenced the molt frequency. One hypothesis on the mechanisms involved in triggering molting when threshold of energy become sufficient is the implication of the hormonal control involving the molt inhibiting hormone $(\mathrm{MIH})$ and the hyperglycaemic hormone $(\mathrm{CHH})(\mathrm{Chang}$ and Mykles, 2011). It is accepted that ecdysis is initiated when blood levels of the MIH fall, which could be triggered by accumulated nutritional energy level. The $\mathrm{CHH}$, which has also a molt inhibiting activity, is produced under various stresses, including food reduction or starvation (Keller and Orth, 1990). Raised CHH levels have been suggested as a possible factor in extending the intermolt period beyond its normal length with reduction in food supply (Oh and Hartnoll, 2000). We showed also that, for an equivalent VFI or energy intake, the dietary level of SPC or protein influenced the molt frequency which was highest for the diet SPC-42. The molt frequency increased from diet SPC-12 to diet SPC-42 and then decrease for the diets SPC-52 and SPC-60. These results are novel and we could hardly find an equivalent study showing the influence of dietary protein on the molts frequency of crustaceans (Regnault and Luquet, 1974). The lower molt frequency of the crabs fed on diet SPC-12 could be explained by a deficiency in protein and essential amino acids required for tissue growth especially during postmolt period. This can also be explained by the high carbohydrate content of the diet SPC-12 which can lead to glucose load resulting in persistent hyperglycemia and growth impairment. However, this second explanation is unlikely, because base on the reported findings for different fish and shrimp species, the maximum recommended levels of digestible 
starch inclusion in feed fall within $20-40 \%$ in shrimp and up to $50 \%$ in omnivorous species among which is the mud crab (La Sara et al., 2007; NRC, 2011).

To explain the decline in molts frequency for the diets SPC-52 and SPC-60, two hypotheses can be put forward: the first relates to the toxicity of ammonia and the second to the antinutritional factors encountered in soy bean.

Regarding the first hypothesis, after feeding the majority of amino acids in excess of what is required for protein synthesis, are catabolized in the liver (Campbell, 1991), releasing ammonia and resulting in transient increases in plasma ammonia level and ammonia excretion rate in fish (Wicks and Randall, 2002). In crustaceans, ammonia, excreted by the gills as the forms of non-ionic ammonia $\left(\mathrm{NH}_{3}\right)$ and ammonium ions $\left(\mathrm{NH}_{4}{ }^{+}\right)$existing in a $\mathrm{pH}$-dependent equilibrium, is the major form of nitrogen excreted, accounting for more than $80 \%$ of the total nitrogen excretion (Needham, 1957; Krishnamoorthy and Srihari, 1973; Weihrauch et al., 2009). During the molt cycle an increase in nitrogen metabolism is correlated with a simultaneous increase in general metabolism (Regnault, 1979). Thus a good correlation exists between ammonia excreted and oxygen consumed. Both were highest immediately after ecdysis or after a meal (Regnault, 1979). For S. serrata, there is also a positive correlation between ammonia excreted and meal size as well as dietary proteins of the diets found in our previous study (unpublished). Thus, a transient postprandial surge in blood ammonia concentration could occur in crabs as it has been described for fishes (Kaushik and Teles, 1985; Wicks and Randall, 2002) and lead to postprandial ammonia toxicity. In our study, crabs fed on diets SPC-52 and SPC-60, with the highest dietary protein content, could be confronted with ammonia toxicity after feeding, leading to lower molt frequency compared to animals fed SPC-42 diet.

The second hypothesis could explain the negative effect of high SPC inclusions on molt frequency of juvenile crabs $S$. serrata. Anti-nutritional factors (ANFs) are present in soy bean meal, such as protease inhibitors, tannins, lectins and non-starch polysaccharides (Francis et al., 2001). However, in our study SPC has been used and produced by aqueous alcohol extraction from defatted soybeans, which removes a majority of the phytate, lectins, saponins and oligosaccharides (Anderson and Wolf, 1995; Bureau et al., 1998; Deng et al., 2006; Refstie et al., 2001). Although SPC has a low content of ANFs, they could still be a significant problem when SPC is included at high levels in the diet. S. serrata may be particularly susceptible to these anti-nutritional factors.

\subsection{Growth}


Most growth studies on crabs only consider the increase in size and fresh weight with time. The highest increase in fresh weight (almost 90\%) of the crab S. serrata occurs in the very brief period of rapid water uptake (Heasman, 1980). Fresh weight changes follow a basic pattern through the molt cycle in all species of crustaceans, i.e. large and abrupt increases associated with rapid water uptake at ecdysis. Further moderate gains are associated with mineralization of the integument and the accumulation of organic matter during late molt stages and a relative stabilization of fresh weight during intermolt until the onset of the successive ecdysis (Heasman, 1980). The water content (\% of fresh body weight) of juvenile S. serrata had a clear and progressive decline from a maximum of $88 \%$ following ecdysis to an average baseline of $62.4 \pm 0.6 \%$. Our results are in close to those of Heasman (1980). The high percentage of free water levels after ecdysis largely reflect the relative amount of water absorbed during and immediately after ecdysis and hence the relative increase in volume of the animal. Although the weight growth in crabs in connection with the molt has an interrupted character, the somatic growth and the accumulation of energy reserves in tissues are continuous processes. Consequently, such growth is accompanied by definite changes in the ratio of dry and fresh weight during the molt cycle. Thus the period of rapid water uptake associated with ecdysis in S. serrata is followed by an increase in dry matter content in the relative proportion of initial body dry weight, reaching a plateau 30 days after ecdysis. The most rapid growth rate occurred during the first days after molt and then decreased until the next molt. Our results are in similar to those of Heasman (1980) who showed that increases in organic matter, as a proportion of fresh weight, were higher from molt stages B to C3 (postmolt stages) than from molt stage C4 to D2 (intermolt-premolt stages) for S. serrata. According Passano (1960) and Skinner (1966), the growth of the muscle is thought to occur during the postmolt period when the carapace is already hardened, whereas immediately after the molt when the carapace is still soft the muscles appear to be watery and atrophied.

Protein gain expressed as the relative proportion of initial body dry weight followed the tissue growth rate pattern. The proportion increased during the first 35 days after ecdysis. This increase reflected a high protein accretion during the postmolt period. El Haj and Houlihan (1987) also showed an increase of the protein synthesis rate in the extensor muscle during the post-ecdysial period of the crab C. maenas.

The changes in the lipid gain were similar to those of tissue and protein. Lipids were accumulated by the crab during the first 40 days following ecdysis reaching a plateau at 8.49 $\pm 0.67 \%$ of the body dry weight. In our previous study we showed that lipid level was higher 
in premolt crabs than in postmolt crabs (unpublished). Furthermore, Copeman et al. (2012) found that triacylglycerol levels in "red king crab" (Paralithodes camtschaticus) rapidly accumulated during seven days following a molt. In Eriocheir sinensis, the accumulation of lipids prior to molting appeared to result from the increase in neutral lipids because the polar lipid content remained constant during the molt cycle. The neutral lipids, particularly triacylglycerides, are the predominant molecules of energy storage and, consequently, the major source of energy (Stoner et al., 2010). In our previous study (unpublished), lipid concentration of dry body in premolt S. serrata $(2.8 \%)$ was lower than those reported for the crab Rhithropanopeus harrisii (5\%) (Nates and McKenney, 2000), the rock lobster Panulirus cygnus (7\%) (Liddy et al., 2005) and red king crab, Paralithodes camtschaticus (2 to 3.6\%) (Stoner et al., 2013).

Conversely to tissue, protein and lipid gains, the proportion of mineral salts (in dry weight) increased rapidly during the 5 days following ecdysis and then reach a plateau until the next molt. Heasman (1980) already noted the rapid mineralization of the cuticle for newly molted S. serrata. Similarly, the crab Eriocheir sinensis actively incorporated minerals after ecdysis (Tian et al., 2012).

In our study we found a linear relationship between VFI (or energy intake) and growth and based on this correlation we calculated the adjusted means of growth for a same amount of energy intake. Tissue growth for a same amount of VFI was not significantly affected by the feed composition, although a higher value was observed with treatment SPC-42. This diet resulted in a better FCR, PER, and retention of protein, lipid and energy. The higher lipid and energy retention of crabs fed on SPC-42 diet must be related to the increase in their molt frequency. This result is consistent with Adelung (1971) who found that the principal determinant of molt frequency in crab C. maenas was its rate of tissue growth. This author also stated that reserve of energy must be accumulated before a molt can occur. In our study, tissue growth and energy storage were faster with diet SPC-42 and the next molt occurred earlier compared with crabs fed on other diets. This would explain the higher molt frequency observed for the crabs fed on SPC-42.

This study has also shown that the quantity or composition of the diet greatly influenced somatic growth and molting frequency, but that they have no influence on the increase in size at ecdysis. According to Hartnoll (1982), the overall growth rate of crustaceans is a function of the molt cycle duration and the molt increment. The relative importance of these two processes varies between species, and within species between different experimental 
protocols. However, in most cases the most important factor is molt cycle duration. Our results on S. serrata are consistent with those in the literature (Hartnoll, 1982).

The best growth (tissue growth and molt frequency) and the best feed efficiency (FCR, PER, retention of energy, proteins and lipids) obtained with SPC-42 diet was confirmed by the bioenergetic study. A decreased of retained energy (RE) was observed when dietary protein content increased. The best RE was observed for the diet SPC-42. Increased energy retention in lower dietary protein diets (SPC-42 and SPC-32) may be related to the efficiency of nutrient utilization. Excess dietary protein is diverted for catabolism creating an imbalance in the nutrient profile of the diets, reducing protein retention (Guzman et al., 2001). Furthermore, it has been demonstrated in young pigs that dietary protein is used less efficiently than carbohydrate or lipid for energy retention (Van Milgen et al., 2001). If a similar process is occurring for crabs in our study, it should result in increased heat production leading to higher energy allocated for maintenance (HEm) and increased urinary energy losses in diets SPC-52 and SPC-60.

The best growth (somatic growth and molt frequency) and the best feed efficiency were obtained, under our experimental conditions, when $1 \mathrm{~kg}$ crabs consumed daily $6.5 \pm 1.1 \mathrm{~g}$ of protein $\left(\mathrm{P} / \mathrm{E}=22.13 \mathrm{~g} \mathrm{Mj}^{-1}\right)$. This ingestion rate was obtained with the diet SPC-42 that contained $40 \%$ protein of which almost three quarters was derived from SPC. Intake of protein with diets SPC-12 and SPC-32 was obviously insufficient for optimal growth, while the excess intake of protein (or SPC) with diets SPC-52 and SPC-60 adversely affected the growth of juvenile crabs. Our results are similar to those of Catacutan (2002) who has shown that the optimal dietary protein in diet was $40 \%$ for juvenile crabs. However, at a younger stage, crabs had much higher voluntary feed intake $\left(21.8 \mathrm{~g} \mathrm{~kg}^{-1}\right.$ of BW d$\left.{ }^{-1}\right)$ and the optimum level of crude protein in the diet was 45\% (Unnikrishnan and Paulraj, 2010). Finally our work demonstrated the advantage of following somatic growth and molt frequency when investigating nutritional requirements of the crab which is subject to very significant changes in water content during the molting cycle.

\section{Acknowledgements}

This study was sponsored by the Southern Province of New-Caledonia and the MOM project. We express our thanks to Dr. David Smith for his valuable comments and English correction of this paper. We would like to thank Mr. Stéphane MENGANT (a technician in the 
Biotechnology laboratory of New Caledonia University) who helped in the chromium analyze and Mr. Thomas Denis (ESA, Angers, France) who participated in experimental diet preparation. We thank all the IFREMER staffs at the Département Aquacole en Calédonie who kindly supported us with the construction, and guiding the nitrogenous analyses using facilities in the laboratory.

\section{References}

Adelung, D., 1971. Untersuchungen zur Häutungsphysiologie der Decapoden Krebse am Beispiel der Strandkrabbe Carcinus maenas. Helgoländer wiss. Meeresunters 22, 66119.

Allan, G., Fielder, D., 2003. Mud crab aquaculture in Australia and Southeast Asia in Proceedings of the ACIAR Crab Aquaculture Scoping Study and Workshop 28-29 April 2003, Joondooburri Conference Centre, Bribie Island.

Amaya, E.A., Davis, D.A. Rouse, D.B., 2007a. Replacement of fishmeal in practical diets for the Pacific white shrimp (Litopenaeus vannamei) reared under pond conditions. Aquaculture 262, 393 - 401.

Amaya, E., Davis, D.A., Rouse, D.B., 2007b. Alternative diets for the Pacific white shrimp Litopenaeus vannamei. Aquaculture 262, 419-425.

Anderson, R.L., Wolf. W.J., 1995. Compositional changes in trypsin inhibitors, phytic acid, saponins and isoflavones related to soybean processing. Journal of Nutrition 125, 581588 .

AOAC, 1995. Meat and meat products. In: Official Methods of Analysis, 16th Ed., Association of Official Analytical Chemists International, Virginia.

Bureau, D.P., Harris, A.M., Cho, C.Y., 1998. The effects of purified alcohol extracts from soy products on feed intake and growth of chinook salmon (Oncorhynchus tshawytscha) and rainbow trout (Oncorhynchus mykiss). Aquaculture 161, 27-43.

Campbell, J.W., 1991. Excretory nitrogen metabolism. In: Prossker, C.L. (Ed.), Comparative Animal Physiology, vol. 1 Environmental and Metabolic Physiology. Wiley-Liss, New York, pp. 277-324.

Catacutan, M.R., 2002. Growth and body composition of juvenile mud crab, Scylla serrata, fed different dietary protein and lipid levels and protein to energy ratios. Aquaculture 208, 113-123. 
Catacutan, M.R., Eusebio, P.S., Teshima, S.I., 2003. Apparent digestibility of selected feedstuffs by mud crab, Scylla serrata. Aquaculture 216, 253-261.

Chang, E. S., Mykles, D.L., 2011. Regulation of crustacean molting: a review and our perspectives. General and Comparative Endocrinology 172, 323-330.

Chen, L.Q., Du, N.S., Lai, W. 1994. Evaluation of soybean cake as a substitute for partial fish meal in formulated diets for Chinese mitten-handed crab juvenile. Journal of Fish China 18, 24-31 (in Chinese) cited in Jang, H.B., Chen, L.Q., Quin, J.G., Gao, L.J., Li, E.C., Yu, N., Sun, S.M., Jiang, X.Q., 2013. Partial or complete substitution of fish meal with soybean meal and cottonseed meal in Chinese mitten crab Eriocheir sinensis diets. Aquaculture International 21, 617-628.

Christensen, S.M., Macintosh, D.J., Phuong, N.T., 2004. Pond production of the mud crabs Scylla paramamosain (Estampador) and $S$. olivacea (Herbst) in the Mekong Delta,Vietnam, using two different supplementary diets. Aquaculture Research 35, 1013-1024.

Copeman, L.A., Stoner, A.W., Ottmar, M.L., Daly, B., Parrish, C.C., Eckert, G.L., 2012. Total lipid, lipid classes, and fatty acids of newly settled red king crab (Paralithodes camtschaticus) juveniles in Alaska, USA, Aquaculture 293, 68-73.

Davis, D.A., Arnold, C.R., 2000. Replacement of fishmeal in practical diets for the Pacific white shrimp, Litopenaeus vannamei. Aquaculture 185, 291- 298.

Deng, J., Mai, K., Ai, Q., Zhang,W., Wang, X., Xu,W., Liufu, Z., 2006. Effects of replacing fish meal with soy protein concentrate on feed intake and growth of juvenile Japanese flounder, Paralichthys olivaceus. Aquaculture 258, 503-513.

Drach, P., Tchernigovtzeff, C., 1967. Sur la me'thode de de'termination des stades d'intermue et son application ge'ne'rale aux Crustace's (in French with English abstract). Vie Milieu 18, 595-610.

El Haj, A. J., Houlihan, D. F. 1987. In vitro and in vivo protein synthesis rates in a crustacean muscle during the moult cycle. Journal of experimental Biology 127, 413-426.

Elliot, J.M., 1976. Energy losses in the waste products of brown trout (Salmo trutta L.). Journal of Animal Ecology 45, 561-580.

FAO, 2000. FAOTAT Database. Food and Agriculture Organization of the United Nations.

Francis, G., Makkar, H.P.S., Becker., K., 2001. Anti-nutritional factors present in plant- 
derived alternate fish feed ingredients and their effects in fish. Aquaculture 199, $197-$ 227.

Freeman, J.A., 1990. Molt increment, molt cycle duration, and tissue growth in Palaemonetes pugio Holthuis larvae. Journal of Experimental Marine Biology and Ecology 143, 47 61.

Freeman, J.A., Kilgus, G., Laurendeau, D., Perry, H.M., 1987. Postmolt and intermolt cycle stages of Callinectes sapidus. Aquaculture 61, 201-209.

Furukawa, A., Tsukahara, H., 1966. On the acid digestion method for the determination of chromic oxide as an index substance in the study of digestibility of fish feed. Nippon Suisan Gakkaishi 32, 502-506.

Gatlin, D.M., Barrows, F.T., Brown, P., Dabrowski, K., Gaylord, T.G., Hardy, R.W., Herman, E., Hu, G., Krogdahl, A., Nelson, R., Overturf, K., Rust, M., Sealey, W., Skonberg, D., Souza, E.J., Stone, D., Wilson, R., Wurtele, E., 2007. Expanding the utilization of sustainable plant products in aquafeeds: a review. Aquaculture Research 38, 551-579.

Grasshoff, K., Erhardt M., Kremling K., 1983. Methods of Seawater Analysis, Verlag Chemie, New York, pp 158-262.

Guzman, C., Gaxiola, G., Rosa, C., Torre-Blanco, A., 2001. The effect of dietary protein and total energy content on digestive enzyme activities, growth and survival of Litopenaeus setiferus (Linnaeus 1767) postlarvae. Aquaculture Nutrition 7, 113-122.

Hammerrsmith Marketing Ltd., 2008. Hammerrsmith.blogspot.com.

Hartnoll, R.G., 1982. Growth. In: The biology of Crustacea, Vol.2, Bliss, D.E. (Ed.), Academic Press, New York, pp. 742-753.

Heasman, P.N., 1980. Part II: Molt cycle dependent changes in the gross composition of juvenile S. serrata. Aspects of the general biology and fishery of the mud crab Scylla serrata (Forskal) in Moreton Bay, Queensland. Ph.D thesis. University of Queensland.

Hertrampf, J.W., Piedad-Pascual, F., 2000. Handbook on Ingredients for Aquaculture Feeds,. Kluwer Academic Publishers, Dordrecht, the Netherlands, pp. 573.

Jiang, H.-B., Chen, L.-Q., Qin, J.-G., Gao, L.-J., Li, E.-C., Yu, N., Sun, S.-M., Jiang. X.-Q. 2013. Partial or complete substitution of fish meal with soybean meal and cottonseed meal in Chinese mitten crab Eriocheir sinensis diets. Aquaculture International 21, 617-628. 
John, S., Paul, C., 2012. Mud crab farming in Asia. Aquaculture: Farming aquatic animals and plants, $2^{\text {nd }}$ edition. USA, Oxford: Wiley-Blackwell.

Johnston, M.D., Johnston, J.D., 2007. Stability of Formulated Diets and Feeding Response of Stage I Western Spiny Lobster, Panulirus cygnus, Phyllosomata. Journal of the World Aquaculture Society 38, 262-271.

Kaushik, S.J., Teles, A., 1985. Effect of digestible energy on nitrogen and energy balance in rainbow trout. Aquaculture 50, 89-101.

Keller, R., Orth, H.-P., 1990. Hyperglycemic neuropeptides in crustaceans. In: Scanes, C.C., Stetson, M.H. (Eds), Progress in Comparative Endocrinology. John Wiley and Sons, New York, 265-271.

Krishnamoorthy, R.V., Srihari, K., 1973. Changes in the patterns of the freshwater field crab Paratelphusa hydrodromous upon adaptation to higher salinities. Marine Biology 21, 341-348.

La Sara, Aguilar, R.O., Laureta, L.V., Baldevarona, R.B., Ingles, J.A., 2007. Natural Diet ofthe Mud Crab (Scylla serrata) in Lawele Bay, Southeast Sulawesi, Indonesia. The Philippine Agricultural Scientist 90, 6-14.

Liddy, G.C., Kolkovski, S., Nelson, M.M., Nichols, P.D., Phillips, B.F., Maguire, G.B., 2005. The effect of PUFA enriched Artemia on growth, survival and lipid composition of western rock lobster, Panulirus cygnus, phyllosoma. Aquaculture Nutrition. 11, 375384.

Linder, B., 2005. Impacts of mud crab hatchery technology in Vietnam. Impact Assessment Series Report No.36. ACIAR projects FIS/1992/017 and FIS/1999/076.

Luo, Z., Li, X.-D., Wang, W.-M., Tan, X.-Y., Liu, X., 2011. Partial replacement of fish meal by a mixture of soybean meal and rapeseed meal in practical diets for juvenile Chinese mitten crab Eriocheir sinensis: effects on growth performance and in vivo digestibility. Aquaculture Research 42, 1616-1622.

Nates, S.G., McKenney Jr., C.L., 2000. Growth, lipid class and fatty acid composition in juvenile mud crabs (Rhithropanopeus harrisii) following larval exposure to Fenoxycarb, insect juvenile hormone analog. Comparative Biochemistry and Physiology 127, 317-325.

Needham, A.E., 1957. Factors affecting nitrogen excretion in Carcinus maenas (Pennant). 
Physiol. Comp. Oecol. 4, 209-239.

NRC (National Research Council), 2011. Nutrient Requirement of Fish and Shrimp. The National Academy Press, Washington, D.C. US.

Oh, C.-W., Hartnoll, R.G., 2000. Effects of food supply on the growth and survival of the common shrimp, Cangon crangon (Linnaeus, 1758) (Decapoda, Caridea). Crustaceana 73, 83-99.

Passano, L. M., 1960. Molting and its control. In: Waterman, T. H. (Ed.). The physiology of Crustacea. Vol. 1. Academic Press, New York, pp. 473-536.

Petersen, E.H., Phuong, T.H., Dung, N.V., Giang, P.T., Dat, N.K., Tuan, V.A., Nghi, T.V., Glencross, B.D., 2013. Bioeconomics of mud crab, Scylla paramamosain, culture in Vietnam. Reviews in Aquaculture 5, 1-9.

Rana, K.J., Siriwardena, S., Hassan, M.R., 2009. Impact of rising fish ingredient prices on aquafeeds and aquaculture production. FAO Fisheries and Aquaculture Technical Paper No. 541. FAO Rome, Italy, pp. 6-12.

Refstie, S., Storebakken, T., Baeverfjord, G., Roem, A.J., 2001. Long-term protein and lipid growth of Atlantic salmon (Salmo salar) fed diets with partial replacement of fish meal by soy protein products at medium or high lipid level. Aquaculture 193, 91-106.

Regnault, M., 1979. Ammonia excretion of the sand-shrimp Crangon crangon (L.) during the moult cycle. Journal of Comparative Physiology 133, 199-204.

Regnault, M., Luquet, P. 1974. Besoins en protéines de la crevette grise Crangon crangon au cours de la croissance. Ann. Nutr. Aliment, 28, 523-537.

Sheen, S.S., Wu, S.W., 1999. The effects of dietary lipid levels on the growth response of juvenile mud crab Scylla serrata. Aquaculture 175, 143-153.

Sheen, S.S., 2000. Dietary cholesterol requirement of juvenile mud crab Scylla serrata. Aquaculture 189, 277-285.

Shepherd, J.C., Jackson, J.A., 2013. Review paper. Global fishmeal and fish-oil supply: inputs, outputs and markets. Journal of fish Biology, doi: 10.1111/jfb.12224.

Shelley C., Lovatelli A., 2011. Mud crab aquaculture. A practical manual. FAO, Fisheries and Aquaculture Technical Paper, Vol. 567, Rome, pp 78.

Skinner, D. M., 1966. Breakdown and reformation of somatic muscle during molt cycle of the 
land crab, Gecarcinusl ateralis. Journal of Experimental Zoology 163, 115-123.

Sookying D., David A.D., Soller Dias Da Silva F., 2013. A review of the development and application of soybean-based diets for Pacific white shrimp Litopenaeus vanamei. Aquaculture Nutrition 19, 441-448.

Stoner, A.W., Ottmar, M.L., Coperman, L.A., 2010. Temperature effects on the molting growth, and lipid composition of newly-settled red king crab, Paralithodes camtschaticus. Journal Experiment Marine Biology and Ecology 393, 138-147.

Stoner, A.W., Copeman, L.A., Ottmar, M.L., 2013. Molting, growth, and energetic of newlysettled blue king crab: Effects of temperature and comparisons with red king crab. Journal of Experimental Marine Biology and Ecology 442, 10-21.

Suárez, J.-A., Gaxiola G., Mendoza, R., Cadavid, S., Garcia, G., Alanis, G., Faillace, J., Cuzon, G., 2009. Substitution of fish meal with plant protein sources and energy budget for white shrimp Litopenaeus vannamei (Boone, 1931). Aquaculture 289, 118 123.

Tacon, A.G.J., Dominy, W.G., 1999. Overview of world aquaculture and aquafeed production. Book of Abstracts. World Aquaculture 99, 26 April - 2 May, Sydney, Australia. World Aquaculture Society, Baton Rouge. L.A. pp. 853.

Tian, Z., Kang, X., Mu, S., 2012. The molt stages and the hepatopancreas contents of lipids, glycogen and selected inorganic elements during the molt cycle of the Chinese mitten crab Eriocheir sinensis. Fish Science 78, 67-74.

Truong, P.H., Anderson, A.J., Mather, P.B., Paterson, B.D., Richardson, N.A., 2008. Effect of selected feed meals and starches on diet digestibility in the mud crab, Scylla serrata. Aquaculture Research 39, 1778-1786.

Truong, P.H., Anderson, A.J., Mather, P.B., Paterson, B.D., Richardson, N.A., 2009. Apparent digestibility of selected feed ingredients in diets formulated for the sub-adult mud crab, Scylla paramamosain, in Vietnam. Aquaculture Research 40, 322-328.

Tuan,V.A., Anderson, A., Luong-van, J., Shelley, C., Allan, G., 2006. Apparent digestibility of some nutrient sources by juvenile mud crab, Scylla serrata (Forskål 1775). Aquaculture Research 37, 359 - 365.

Unnikrishnan, U., Paulraj, R., 2010. Dietary protein requirement of giant mud crab Scylla serrata juveniles fed iso-energetic formulated diets having graded protein levels. 
Aquaculture Research 41, 278-294.

USSEC (U.S. Soybean Expert Council), 2008. Soy protein concentrate aquaculture feeds technical bulletin. USSEC, St. Louis, Missouri, USA.

Van Milgen, J., Noblet, J., Dubois, S., 2001. Energetic efficiency of starch, protein and lipid utilization, in growing pigs. Journal of Nutrition 131, 1309-1318.

Vega-Villasante, F., Cortés-Jacinto E., García-Guerrero, M., 2007. Contribution to the knowledge of moulting and growth of Callinectes arcuatus ordway 1863 (Brachyura, portunidae) in Baja California Sur, Mexico. Crustaceana. 80(7).

Weihrauch, D., Wilkie, M.P., Walsh P.J., 2009. Ammonia and urea transporters in gills of fish and aquatic crustaceans. The Journal of Experimental Biology 212, 1716-1730.

Wicks, B.J., Randall, D.J., 2002. The effect of feeding and fasting on ammonia toxicity in juvenile rainbow trout, Oncorhynchus mykiss. Aquatic Toxicology 59, 71-82.

\section{Captions of tables and figures}

Table 1. Ingredients and proximal composition of five experimental diets.

Table 2. Apparent digestibilities for dry matter (ADMD), crude protein (ACPD) and gross energy (AGED) of five experimental diets.

Table 3. Voluntary feed intake, SPC (soy protein concentrate) intake and protein intake for crabs fed on five different experimental diets.

Table 4. Feed efficiency in crab juveniles fed on different experimental diets.

Table 5. Energy budget of crabs fed on different experimental diets with the same energy intake.

Figure 1. Voluntary feed intake of crabs fed on whatever the diet, during a molt cycle. Homogenous groups determined from Tukey test are presented above the curve according time.

Figure 2. Cumulative molts of crabs (\% of initial crab numbers) according to the voluntary feed intake (VFI) levels (A) and different diets (B). iBW = fresh initial body weight.

Figure 3. Fresh body weight gain after one day of ecdysis (A) and carapace increment after 
one day of ecdysis (B) for crabs fed on different experimental diets.

Figure 4. Crab water content during a molt cycle. Mean value of the data calculated for crabs after 25 days of ecdysis. The fast decline trend of water content during the first 25 days after ecdysis "O"while stable trend for crabs after 25 days of ecdysis "O".

Figure 5. Growth of crabs during a molt cycle: (A) is tissue gain expressed in $\%$ of dry body weight after ecdysis - \% of dry BWa.e.; mean value was determined for crabs after 25 days of ecdysis and (B) is tissue growth rate expressed in \% of dry body weight after ecdysis per day - \% of dry BWa.e. day ${ }^{-1}$.

Figure 6. Nutrient gains of crabs expressed as \% of dry body weight after ecdysis during a molt cycle: (A) protein gain; (B) lipid gain and (C) ash gain.

Figure 7. Linear relationships between growth rates (\% of dry iBW.day $\left.{ }^{-1}\right)$ and energy intakes of crabs fed on different experimental diets: SPC-32; SPC-42; SPC-52 and SPC-60. Significant ${ }^{2}$, $P=0.10 ; 0.02 ; 0.04 ; 0.03$ for SPC-32; SPC-42; SPC-52; SPC-60, respectively. 


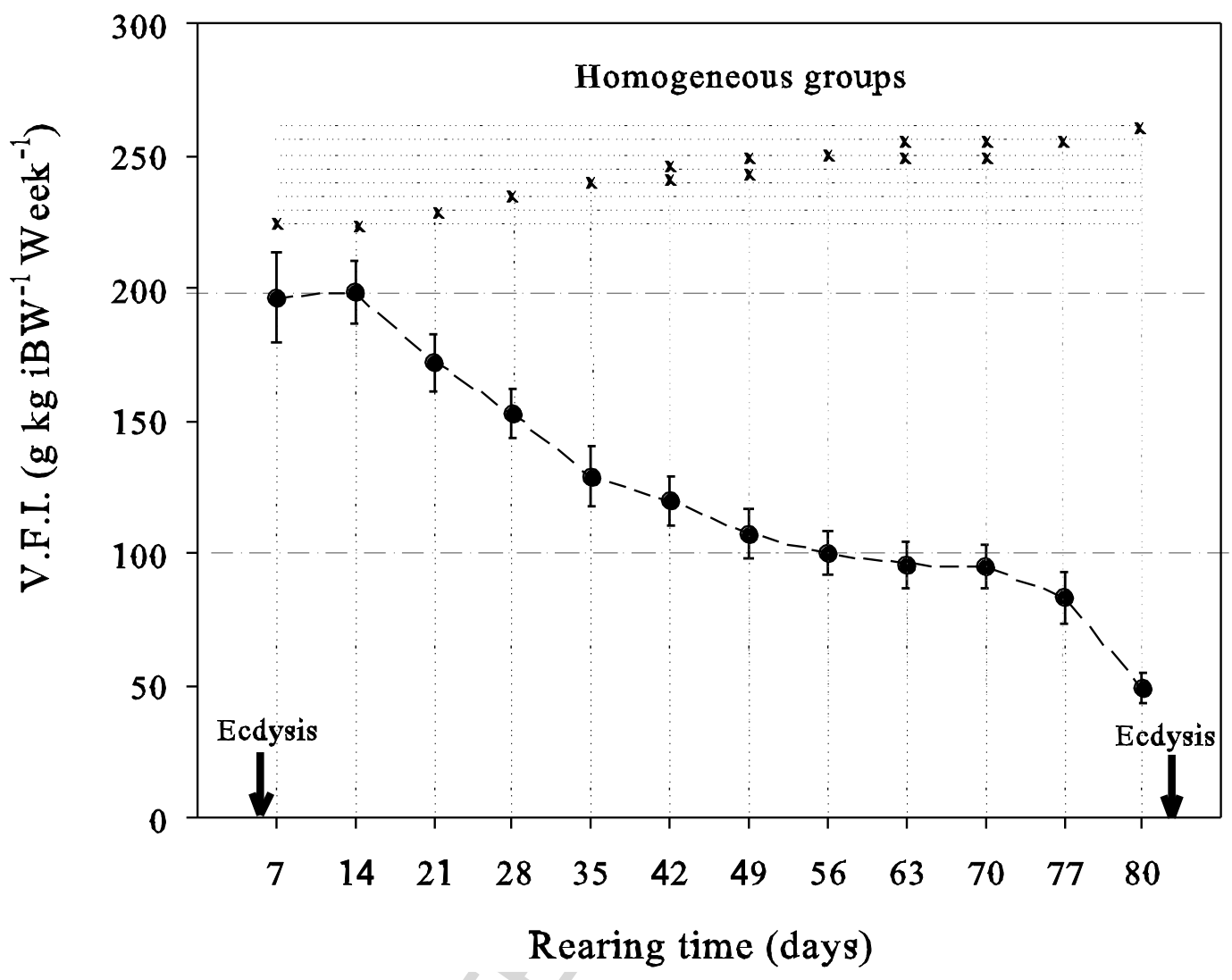

Figure 1 


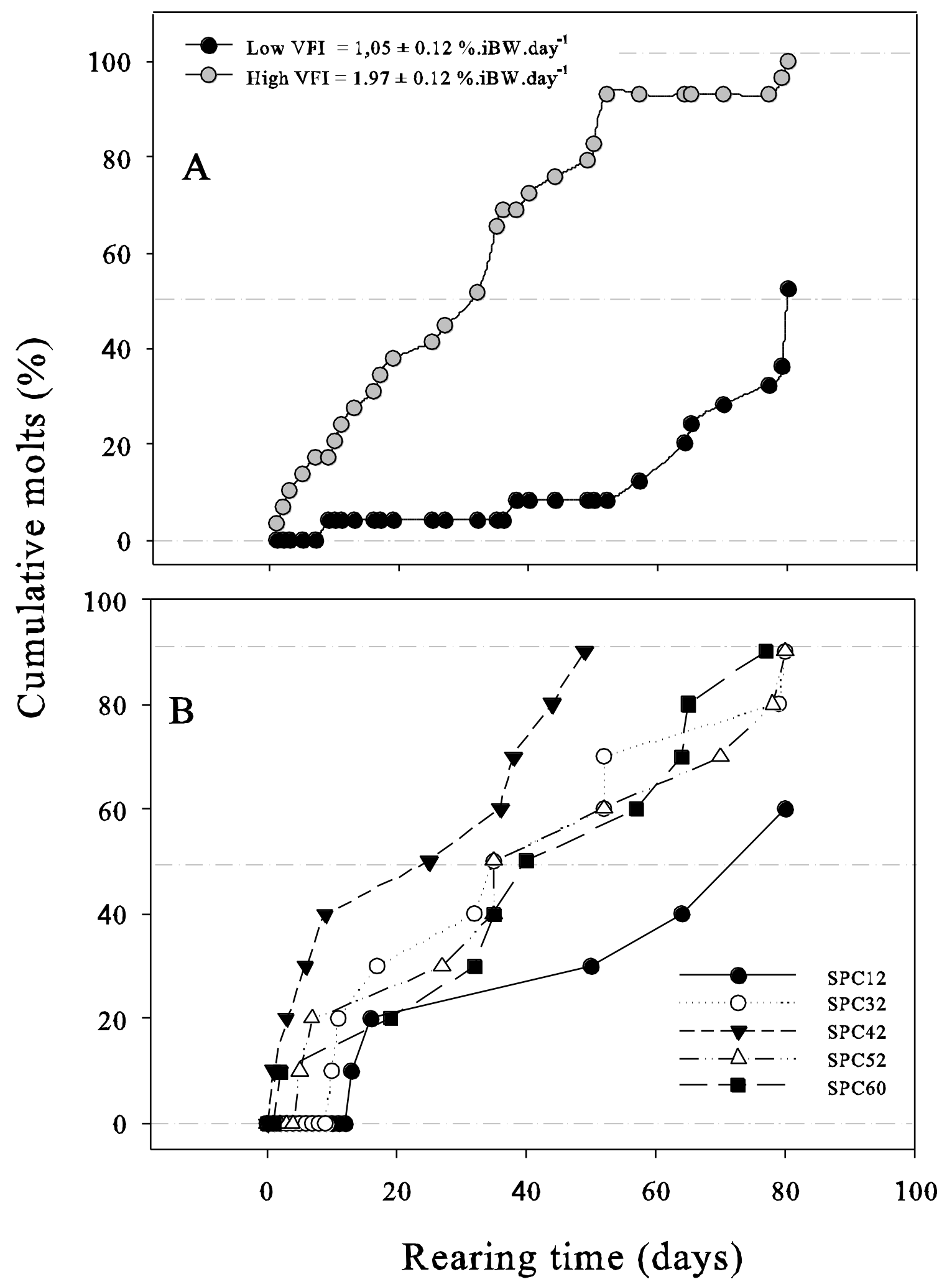

Figure 2 

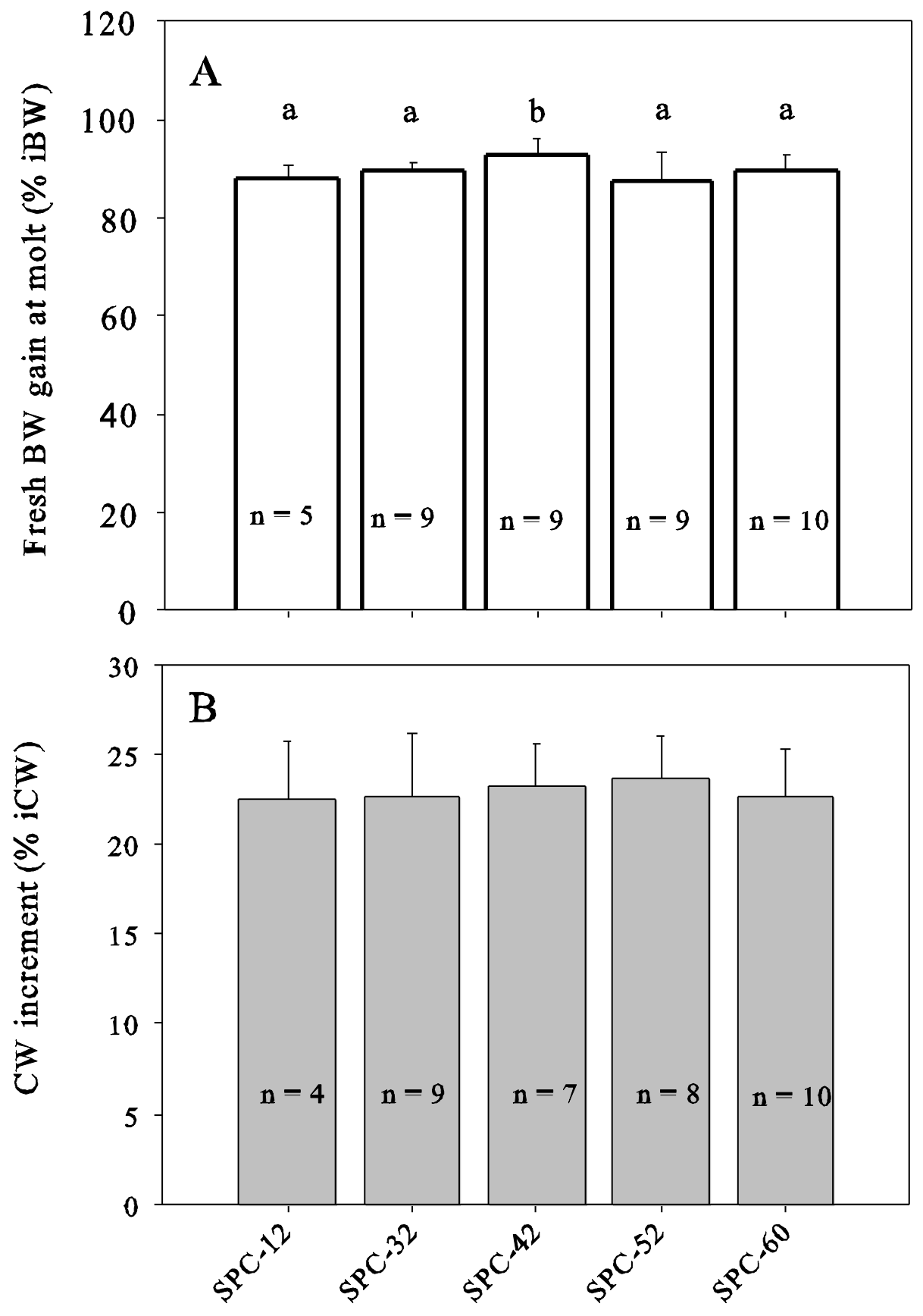

Experimental diets

Figure 3 


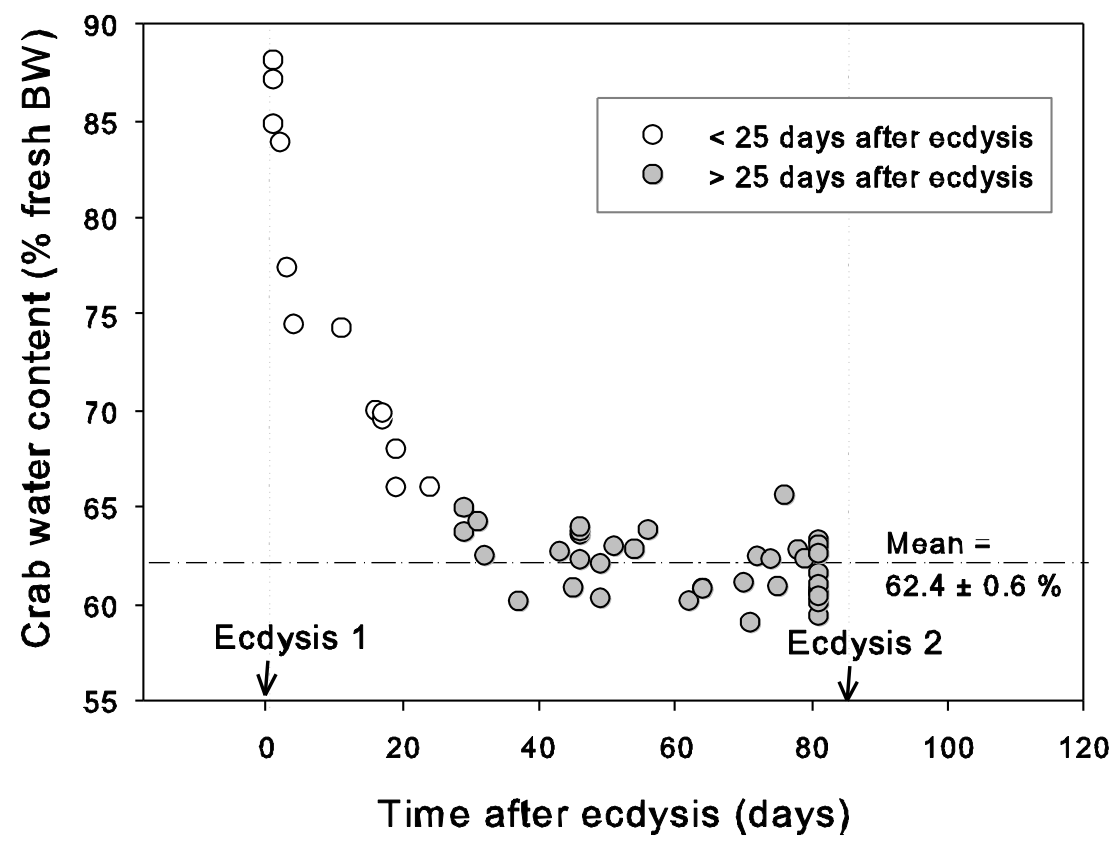

Figure 4 

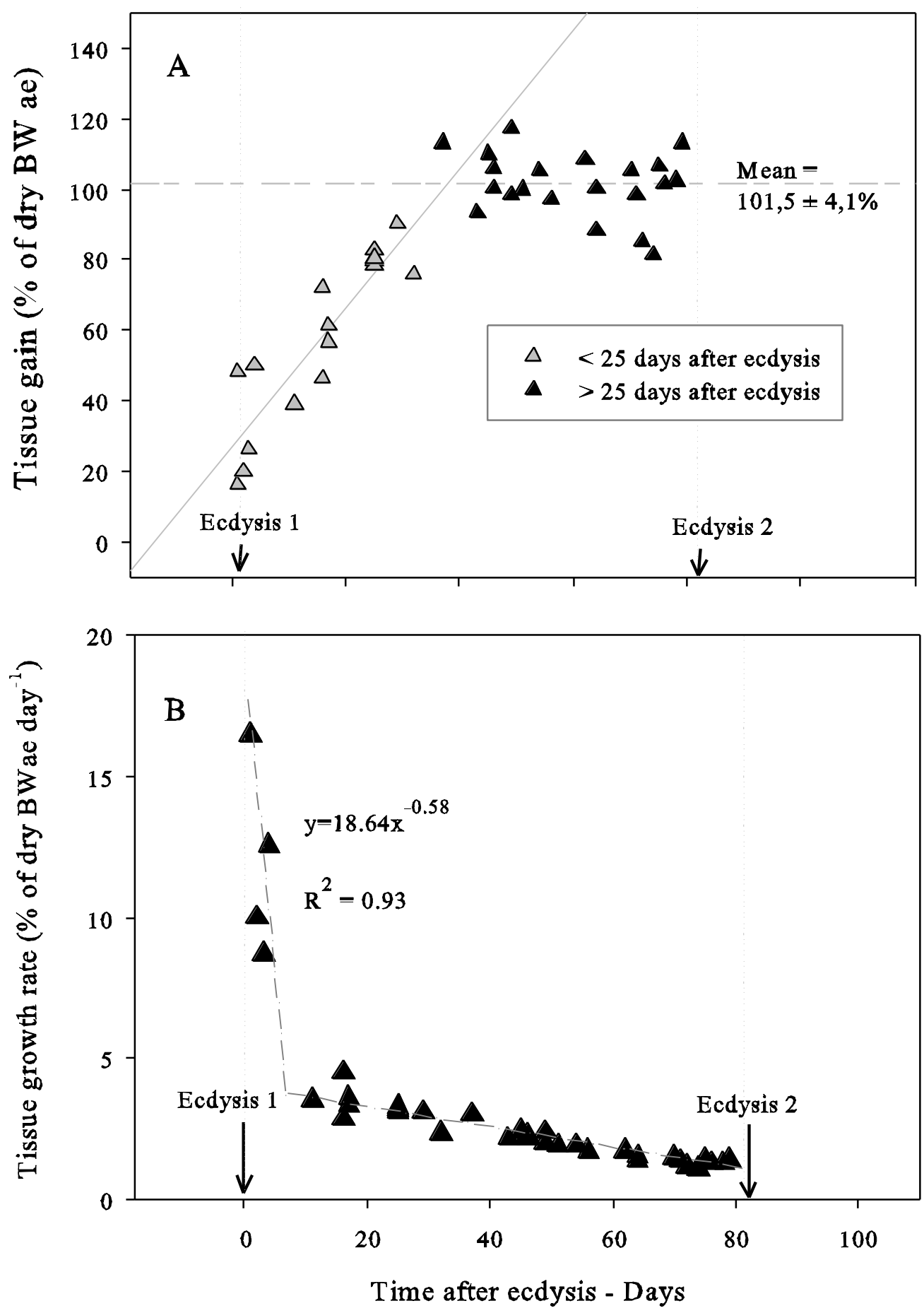

Figure 5 

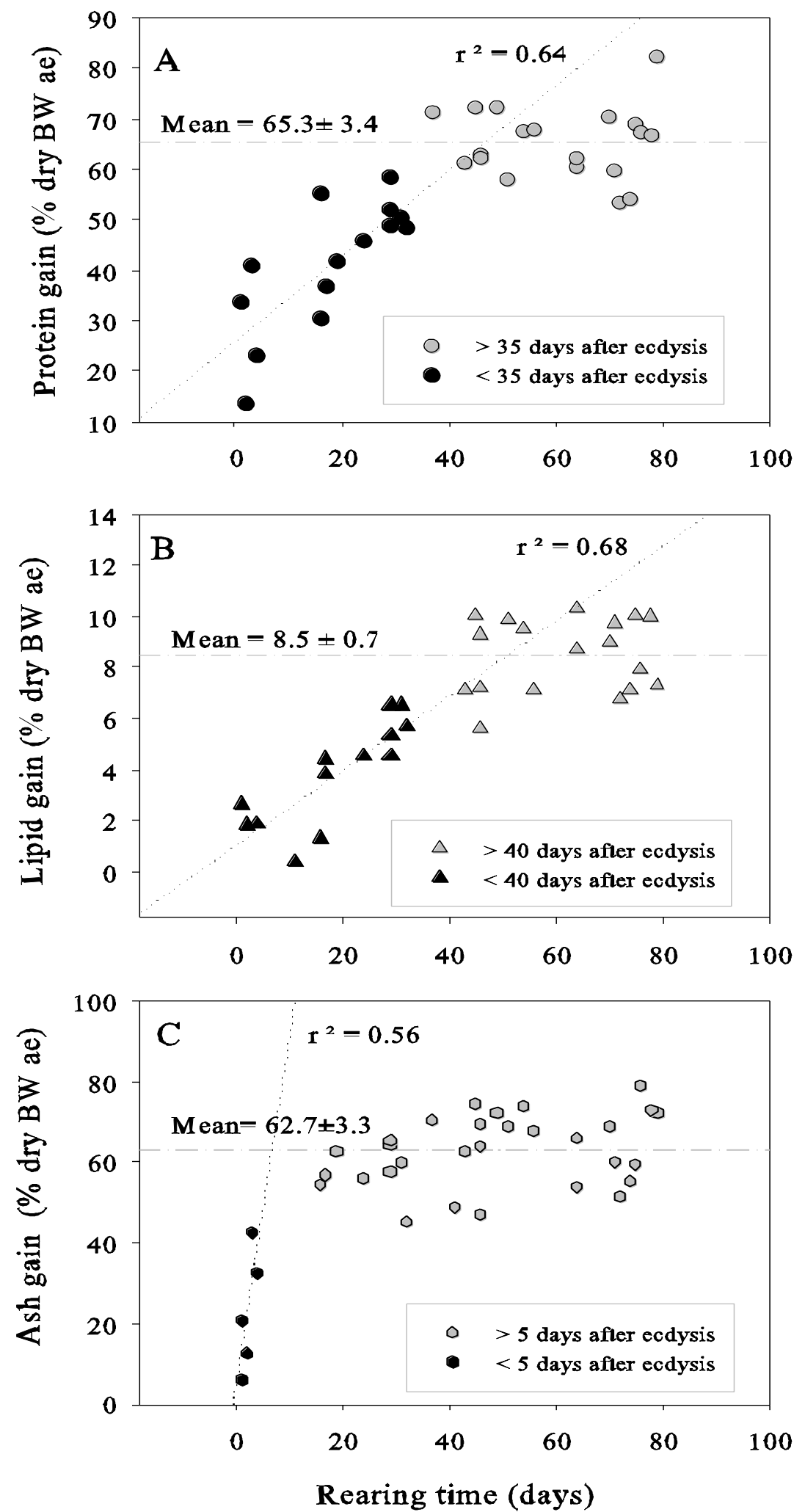

Figure 6 


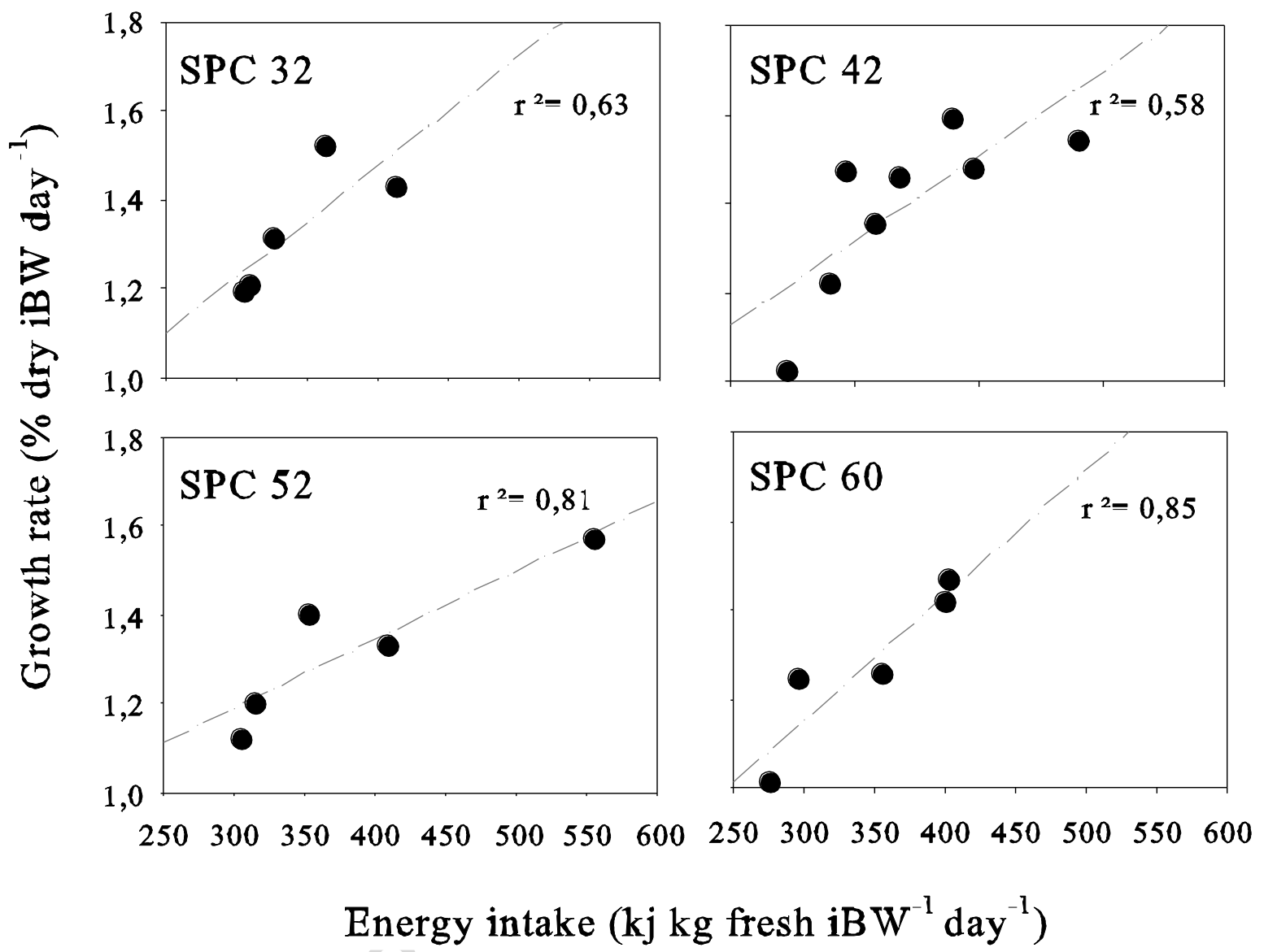

Figure 7 
Table 1. Ingredients and proximal compositions of five experimental diets.

Experimental diets

\begin{tabular}{lllll}
\hline SPC-12 & SPC-32 & SPC-42 & SPC-52 & SPC-60
\end{tabular}

\section{Composition (\%)}

Soy protein concentrate (SPC)

12

32

42

52

60

Crab meal ${ }^{2}$

20

20

20

20

20

Wheat flour ${ }^{3}$

53.5

35.0

25.5

16.0

8.0

Fish oil

4

4

4

4

4

Soy oil

2.5

1.0

0.5

0.0

0.0

Gluten

$5-7$

5

5

5

5

Dicalcium phosphate

$\begin{array}{lllll}3 & 3 & 3 & 3 & 3\end{array}$

vitamin $C^{3}$

0.25

0.25

0.25

0.25

0.25

Vitamin premix ${ }^{4}$

0.5

0.5

0.5

0.5

0.5

Trace elements ${ }^{5}$

1

1

1

1

1

\section{Analysis (dry matter basis)}

Crude protein (\%)

26.87

$35.52 \quad 39.69$

44.15

49.17

Lipid (\%)

6.30

4.80

4.62

4.36

4.43

Ash (\%)

13.95

14.54

22.36

21.80

27.43

Gross energy ( $\mathrm{MJ} \mathrm{kg}^{-1}$ )

17.96

17.26

17.87

18.61

18.44

Protein/Energy $\left(\mathrm{g} \mathrm{Mj}^{-1}\right)$

16.7

20.58

22.13

23.72

25.56

${ }^{1}$ SPC purchased from "Sementes Selecta SA", a Cie in Brazil.

${ }^{2}$ Crab meal purchased from "Comercial Bahia SPA", a Cie based in Chile.

${ }^{3}$ Vitamine C: Rovimix Stay-C 35 from DSM Cie.

${ }^{4}$ Vitamin premix for shrimp from BEC feed solutions PTY, LTD - ingredients: vitamin AD3 1000/200, vitamin B1 98\% Thiamine, Mononitrate, vitamin B2 Riboflavin 80\%, vitamin B3 99\% Niacin, vitamin B5 98\% D-Calpan, vitamine B6 98\% Pyridoxine, vitamin B9 97\% Folic acid, vitamin D3 500, Vitamin E 50 $A D D$, vitamin $\mathrm{K} 343.7 \%$. 
${ }^{5}$ Trace eliments from SICA Cie (Goodman Fielder ${ }^{\odot}$ ). SICA is the main animal feed producer Cie in New Caledonia. 
Table 2. Apparent digestibilities for dry matter (ADMD), crude protein (ACPD), and gross energy (AGED) of five experimental diets.

\begin{tabular}{llll}
\hline \multirow{2}{*}{ Diets } & \multicolumn{2}{l}{ Apparent digestibilities (\%) } \\
\cline { 2 - 4 } & ADMD & ACPD & AGED \\
\hline CP25 & $95.96 \pm 1.44^{\mathrm{a}}$ & $96.85 \pm 0.82^{\mathrm{a}}$ & $96.84 \pm 0.70^{\mathrm{a}}$ \\
CP35 & $95.80 \pm 2.02^{\mathrm{a}}$ & $96.99 \pm 0.92^{\mathrm{a}}$ & $96.47 \pm 0.55^{\mathrm{a}}$ \\
CP40 & $96.29 \pm 1.82^{\mathrm{a}}$ & $97.65 \pm 0.57^{\mathrm{a}}$ & $97.09 \pm 0.42^{\mathrm{a}}$ \\
CP45 & $96.03 \pm 1.04^{\mathrm{a}}$ & $97.12 \pm 0.63^{\mathrm{a}}$ & $97.04 \pm 0.55^{\mathrm{a}}$ \\
CP50 & $96.00 \pm 1.62^{\mathrm{a}}$ & $97.68 \pm 0.34^{\mathrm{a}}$ & $97.67 \pm 0.47^{\mathrm{a}}$
\end{tabular}

Values are means $\pm S D(n=3$ replicates per treatment). Within the same column, means with the same letters are not significantly different $(P>0.05)$.

Table 3. Voluntary feed intake, SPC (soy protein concentrate) intake and protein intake for crabs fed on five different experimental diets.

\begin{tabular}{|c|c|c|c|c|c|}
\hline \multicolumn{6}{|c|}{ Experimental diets } \\
\hline & $\begin{array}{l}S P C-12 \\
(n=10)\end{array}$ & $\begin{array}{l}\text { SPC-32 } \\
(n=11)\end{array}$ & $\begin{array}{l}\text { SPC-42 } \\
(n=11)\end{array}$ & $\begin{array}{l}\text { SPC-52 } \\
(n=11)\end{array}$ & $\begin{array}{l}\text { SPC-60 } \\
(n=11)\end{array}$ \\
\hline $\begin{array}{l}\text { Voluntary feed intake } \\
\left(\mathrm{g} \mathrm{kg}^{-1} \text { of iBW } \text { week }^{-1}\right)\end{array}$ & $96.7 \pm 25.3^{\mathrm{a}}$ & $106.7 \pm 18.6^{a}$ & $114.0 \pm 18.7^{\mathrm{a}}$ & $107.4 \pm 31.0^{\mathrm{a}}$ & $102.7 \pm 21.5^{\mathrm{a}}$ \\
\hline $\begin{array}{l}\text { SPC intake } \\
\mathrm{kg}^{-1} \text { of iBW week }{ }^{-1} \text { ) }\end{array}$ & $11.6 \pm 3.0^{\mathrm{a}}$ & $34.1 \pm 5.8^{b}$ & $47.9 \pm 7.9^{b c}$ & $55.9 \pm 16.1^{b c}$ & $61.6 \pm 12.9^{c}$ \\
\hline $\begin{array}{l}\text { Protein intake } \\
\left(\mathrm{g} \mathrm{kg}^{-1} \text { of iBW week }{ }^{-1}\right)\end{array}$ & $26.0 \pm 6.8^{\mathrm{a}}$ & $37.9 \pm 6.5^{\mathrm{a}}$ & $45.3 \pm 7.4^{b}$ & $47.4 \pm 13.7^{b}$ & $50.5 \pm 10.6^{b}$ \\
\hline
\end{tabular}

Values are means \pm SD. Within the same row, means with different letters are significantly different $(P<0.05)$; iBW = fresh initial body weight.

Table 4. Feed efficiency in crab juveniles fed on different experimental diets.

Parameters

Experimental diets

SPC-12SPC-32 ( $n=5)$ SPC-42 ( $n=7)$ SPC-52 ( $n=5)$ SPC-60 $(n=5)$ 


\begin{tabular}{|c|c|c|c|c|c|}
\hline \multicolumn{2}{|c|}{ Tissue growth rate $\left(\%\right.$ of dry iBW $\left.d^{-1}\right)$ ND } & $0.81 \pm 0.05^{\mathrm{a}}$ & $0.86 \pm 0.06^{\mathrm{a}}$ & $0.76 \pm 0.04^{\mathrm{a}}$ & $0.78 \pm 0.05^{a}$ \\
\hline FCR & ND & $3.88 \pm 0.22^{\mathrm{a}}$ & $3.68 \pm 0.26^{a}$ & $4.07 \pm 0.26^{\mathrm{a}}$ & $4.05 \pm 0.28^{a}$ \\
\hline PER & ND & $0.62 \pm 0.04^{\mathrm{a}}$ & $0.65 \pm 0.04^{\mathrm{a}}$ & $0.59 \pm 0.04^{\mathrm{a}}$ & $0.59 \pm 0.03^{a}$ \\
\hline Protein retention (\%) & ND & $24.95 \pm 1.53^{\mathrm{a}}$ & $26.45 \pm 1.75^{\mathrm{a}}$ & $23.80 \pm 1.55^{\mathrm{a}}$ & $23.98 \pm 1.56^{\mathrm{a}}$ \\
\hline Lipid retention (\%) & ND & $32.65 \pm 2.32^{\mathrm{a}}$ & $35.27 \pm 2.33^{\mathrm{a}}$ & $24.57 \pm 1.21^{b}$ & $25.20 \pm 1.64^{b}$ \\
\hline Energy retention (\%) & ND & $18.48 \pm 1.13^{\mathrm{ab}}$ & ${ }^{x} 18.92 \pm 1.25^{b}$ & $16.35 \pm 1.07^{c}$ & $19.62 \pm 1.08^{b}$ \\
\hline
\end{tabular}

Table 5. Energy budget of crabs fed on different experimental diets with the same energy intake.

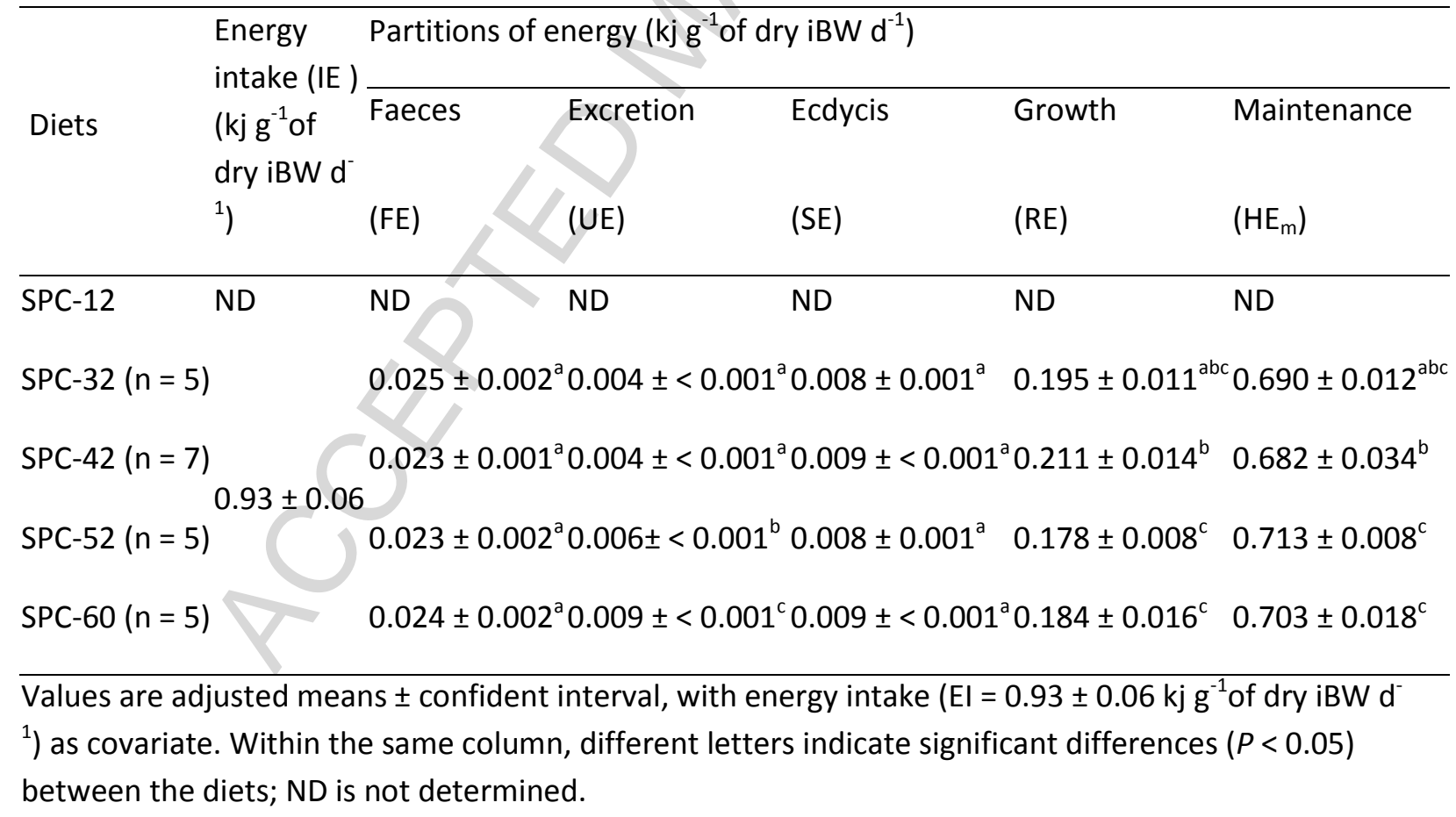

